Mots. Les langages du politique

$94 \mid 2010$

Trente ans d'étude des langages du politique

(1980-2010)

\title{
The Discursive Construction of History. Brief Considerations
}

Ruth Wodak

\section{CpenEdition}

\section{Journals}

Electronic version

URL: https://journals.openedition.org/mots/19862

DOI: $10.4000 /$ mots. 19862

ISSN: 1960-6001

Publisher

ENS Éditions

Printed version

Date of publication: 30 November 2010

Number of pages: $57-65$

ISBN: 978-2-84788-235-3

ISSN: 0243-6450

Electronic reference

Ruth Wodak, "The Discursive Construction of History. Brief Considerations", Mots. Les langages du politique [Online], 94 | 2010, Online since 06 November 2012, connection on 28 April 2022. URL: http:// journals.openedition.org/mots/19862 ; DOI: https://doi.org/10.4000/mots.19862 


\section{Mots \\ Les langages du politique}

№ 94 novembre 2010

\section{Trente ans d'étude des langages du politique (1980-2010)}

ouvrage coordonné par Paul BACOT, Marlène Coulomb-GulLY, Jean-Paul Honoré, Christian Le BART, Claire Oger, Christian Plantin

\section{SOMMAIRE}

Paul Bacot, Marlène Coulomb-Gully, Jean-Paul Honoré, Christian Le Bart, Claire Oger, Christian Plantin

Le discours politique n'est pas transparent. Permanence

et transformations d'un objet de recherche

OUTILS ET ENJEUX DU DISCOURS POLITIQUE

Ruth Amossy, Roselyne Koren

Argumentation et discours politique

Christian Plantin

Argumentation-rhétorique. Les eaux mêlées

Caroline Ollivier-Yaniv

Discours politiques, propagande, communication, manipulation 
Marc Bonhomme

La caricature politique

Paul Bacot

Développement et diversification d'une onomastique politique

Ruth Wodak

The Discursive Construction of History. Brief Considerations

Henri Boyer

Les politiques linguistiques

\section{LIEUX DE LA PRODUCTION DU DISCOURS POLITIQUE}

Christian Le Bart

Parler en politique

Dominique Maingueneau

Le discours politique et son «environnement»

Alice Krieg-Planque, Claire Oger

Discours institutionnels. Perspectives pour les sciences

de la communication

Sophie Béroud, Josette Lefèvre

Le corpus syndical. Une expérience au long cours

Corinne Gobin, Jean-Claude Deroubaix

L'analyse du discours des organisations internationales.

Un vaste champ encore peu exploré

François de la Bretèque

Le retour de la parole politique dans le cinéma français

Jean-Claude Soulages

Vie et mort du citoyen cathodique

Jacques Guilhaumou

Les discours de la Révolution française.

Aperçu d'ensemble d'un trajet de recherche (1980-2009) 


\section{DISCIPLINES ET CHAMPS DE RECHERCHE POUR L'ÉTUDE DES LANGAGES DU POLITIQUE}

Philippe Braud

L'apport de la science politique à l'étude des langages du politique

Claire Blandin

L'apport de l'histoire des médias à l'étude des langages du politique

Jean-François Tétu, Bernard Lamizet

Les SIC et les langages du politique

Sylvianne Rémi-Giraud

Sémantique lexicale et langages du politique.

Le paradoxe d'un mariage difficile?

Marlène Coulomb-Gully, Juliette Rennes

Genre, politique et analyse du discours.

Une tradition épistémologique française gender blind

Johannes Angermüller

Analyser le discours politique en Allemagne (1980-2010)

Érik Neveu

L'apport de Pierre Bourdieu à l'analyse du discours.

D'un cadre théorique à des recherches empiriques

Roselyne Ringoot

Questionner le discours avec Michel Foucault.

Actualisations théoriques et actualité éditoriale

\section{ENTRETIEN}

Maurice Tournier

Mots et politique, avant et autour de 1980

La revue Mots. Les langages du politique encourage l'usage des rectifications de l'orthographe proposées par le Conseil supérieur de la langue française et approuvées par l’Académie (Journal officiel, $n^{\circ}$ 100, 6 décembre 1990). 


\section{The Discursive Construction of History. Brief Considerations}

\section{Discourse studies and the re/writing of History}

In recent years, much research in Discourse Studies and Critical Discourse Studies has started to analyse the many dimensions of national and transnational "identity politics" and to investigate how the discursive construction of such identities draws on collective and individual memories, on hegemonic and common sense narratives, and on myths which are proposed as constitutive for national identification (see below: "Discourses of/about the past(s). Overview of research"). Indeed, one might claim that the entire field of “language and politics" in post-war Europe (particularly since the 1960's and 1980's) was triggered by the desire to understand the influence of persuasive rhetoric in and on totalitarian regimes and related major catastrophes in the $20^{\text {th }}$ century, thus trying to come to terms with the traumatic pasts in Europe and beyond (Wodak, De Cillia, 2006, 2007). In this way, it is very timely to consider the range of research, theories, and methodologies employed to investigate this domain in a special issue dedicated to "thirty years of Mots. Les langages du politique".

It is obvious however, that many answers to overarching questions are still missing, such as: how should one deal with "traumatic" pasts that are prevalent in every society? How should one deal with perpetrators and victims? Should one focus on a common future and "forget the past"? Can a "clean break" be achieved? What are the functions and risks of such a "clean break"? And if silence occurs, what are the consequences, for perpetrators, victims, and society as a whole? In particular, one question remains: are there any global traits with respect to dealing with individual and collective memories? In the following, I summarise some of the most important research related to these questions from the perspective of (Critical) Discourse Studies. 


\section{Discourses of/about the past(s). Overview of research}

Recent research focuses on a range of salient oral, written, and visual genres, such as commemorative speeches at various salient national or transnational days in the Netherlands, Denmark, the US and the UK, Austria and Germany ${ }^{1}$, the discourses of truth and reconciliation tribunals in South Africa, Chile, and Argentina ${ }^{2}$, accounts and experiences of victims (and perpetrators) in the Congo, Austria, France, Poland, and Germany3, the argumentation inherent in election posters insinuating and functionalising past events as well as related xenophobic and anti-Semitic stereotypes (in Austria and the UK) (Distelberger, 2009; Richardson, Wodak, 2009a, 2009b), television debates and documentaries discussing competing narratives of national pasts, in Poland, Hungary, Germany, Austria, the Soviet Union, the UK, and France4, the effect of commemorative exhibitions (Uhl, 2008), the discursive construction of national identities in Austria, Palestine or the UK5, debates in the (Austrian, Israeli or Portuguese) press about the juxtaposition of victims and perpetrators 6 or about issues of restitution (De Cillia, Wodak, 2009b), and representations of victims and perpetrators in school books in Austria and Japan (Barnard, 2003; Loitfellner, 2008).

of course, some studies also investigate counter-discourses by politicians and political parties who continuously endorse revisionist views of the past and attempt to justify or indeed deny past war crimes7. Specific linguistic-rhetorical patterns are also under investigation in this context, such as conceptual metaphors and their blending or the implicatures and presuppositions as employed, for example, in Hitler's Mein Kampf(Chilton, 2007; Musolff, 2009), and the coded languages of racism, xenophobia, and anti-Semitism as well as the related indirect pragmatic devices used to discriminate against certain marginalised social groups or to promote a “politics of denial” (Van Dijk, 1993; Wodak, 2007).

\section{An integrative interdisciplinary framework}

\section{Comparing and/or equating?}

This brief overview is, of course, not a finite list; however, the range of countries and investigated topics becomes apparent, linked to the emergence of

1. De Cillia, Wodak, 2009a; Forchtner, 2010; Stockholm-Banke, 2009; Ensink, 2009; Reisigl, 2008; Charteris-Black, 2007; Slavickova, 2010; Wodak et al., 1994.

2. Achugar, 2008; Anthonissen, Blommaert, 2006; Verdoolaege, 2008.

3. Blommaert, 2005; Carrard, 2010; Ensink, Sauer, 2003; Heer et al., 2008; Wodak, 2006a, 2006b.

4. Blommaert, 2003; Czyżewski, 2009; Kovàcs, Wodak, 2003; Pollak, Wodak, 2008.

5. Wodak et al., 2009; Suleiman, 2010; Blackledge, 2004.

6. Pollak, 2002; Ribeiro, 2010; Zimmerman, 2009.

7. Benke, Wodak, 2003; Wodak et al., 1990; Engel, Wodak, 2009. 
historical and political science literature best summarised in Judt (2007). Judt's seminal book Post-War presents a comprehensive and detailed account of different aspects of the world's responses to (the aftermath of) World War II. He succeeds, in illustrating how specific and indeed diverse the responses in various parts of the world and countries were and are to salient traumatic experiences of the past.

In this vein, Pelinka (2009, p. 49) argues that

[I]n dealing with war crimes and crimes against humanity, three different, sometimes conflicting patterns have been developed since 1945 . The three patterns can be distinguished according to their different guarding principles: Justice: Perpetrators must be brought to court and convicted. Truth: All major aspects of the crimes must become known to the public. Peace: At the end of any process, social reconciliation must become possible.

He continues that "in the short run, neglecting justice and truth in favour of peace and reconciliation may have a positive impact on stabilizing democracy in a peaceful way; but in the long run, such a neglect has its price especially regarding social peace" (ibid.).

More specifically, Pelinka claims that, on the one hand, "without comparing the quality and the quantity of evidence, any debate about conflicting narratives loses any kind of academic liability and responsibility" (p.50), thus comparison should take place, always in a context-dependent way. On the other hand, however, comparisons should not lead to any equation of traumatic events. Thus, Pelinka emphasises that

Fascism is not fascism is not fascism. Too easily the term fascism is used to blur significant differences between different regimes. Spain under Franco is not Italy under Mussolini is not Austria under Dollfuß is not Portugal under Salazar is not Hungary under Horthy - and they all are not Germany under Hitler. All these different types of fascism or semi-fascism have a lot in common - non-democratic rule, oppression of political opponents, ending the rule of law. But the intensity of suppression as well as the existence of a monopolistic mass party make a lot of difference - not to speak of the Holocaust which is the decisive quality of nazism and not of fascism in general. (Ibid., p. 53)

Careful deconstruction of many current debates about the past in different parts of the world illustrates indeed that certain terms become ubiquitous - such as "Holocaust" or "fascism". Following Pelinka's argument (which I endorse), it is obvious that terms lose their distinctiveness when used to label similar but very different events and experiences in different national contexts. Such terms then tend to be employed like "empty signifiers" and their context-dependent meanings become blurred. Hence, research about past events necessarily has to consider the socio-political and historical contexts of each experience and avoid undifferentiated generalisations. 


\section{Four models of coping with traumatic pasts}

Assmann (2009, p. 31 ff.) distinguishes between four ways in which societies deal with traumatic pasts. She refers to them as dialogic forgetting; remembering in order to prevent forgetting; remembering in order to forget; and dialogic remembering. The first - dialogic forgetting - is defined as a model for peace agreed upon by two parties that had engaged in violence in order to keep an explosive past at bay. This kind of forgetting is not to be set equal with the suppression of memories by one side of the conflict; rather, this serves, as Assmann argues, to achieve closure and allow societies to "move on". One of the examples mentioned in this thought-provoking essay are the many traumatic incidents in Spain under Franco until Spanish Prime-minister Zapatero's “memory law" 2007, which for the first time encouraged Spanish people to remember.

"Remembering in order to prevent forgetting" is typical for asymmetric instances of violence. The paradigmatic case in hand is the genocide against Jews and Roma during the Nazi regime (the "Holocaust"). As Assmann claims:

[R]emembering was the only adequate response to such collectively destructive and devastating experiences. It was rediscovered not only as a therapeutic remedy for the survivors but also as a spiritual and ethical obligation for the millions of dead victims. Thus slowly but inevitably, the pact of forgetting was transformed into a "pact of remembering". The aim of such a pact is to transform the asymmetric experience of violence into symmetric forms of remembering. (Ibid., p. 35)

The aim of the third model is also forgetting, but the way to achieve this aim leads through remembering. Remembering in this case (for example, in South Africa or in Chile) is introduced as a therapeutic tool to cleanse and to reconcile. Many linguistic studies have investigated the effect of the Truth and Reconciliation Commission in South Africa (Anthonissen, Blommaert, 2006; Verdoolaege, 2008). Although, of course, only some perpetrators were brought to justice and not all voices of victims were heard, this procedure enabled South African society to avoid a civil war. Finally, Assmann mentions a utopian model, the model of "dialogic remembering": "Two countries engage in a dialogic memory if they face a shared history of mutual violence by mutually acknowledging their own guilt and empathy with the suffering they have inflicted on others" (ibid., 40). Assmann mentions some first attempts at dialogic remembering. For example, she lists the Warsaw uprising, a seminal event commemorated in Poland, which was unknown to Germans because it is fully eclipsed - for the German public - by the Warsaw ghetto uprising. Simultaneously, Germans have reclaimed the firebombing of Dresden for their national memory, but they have neglected the Leningrade Blockade (1941-1944) by the German Wehrmacht, through which 700000 Russians were starved to death; and so forth. 
Recently, such neglected events are increasingly finding their way into history school books and public debates.

\section{Discourse and social change}

In accordance with the two above mentioned theoretical frameworks by Pelinka and Assmann, it is necessary, I believe, to integrate these with concepts from discourse analysis. In this context, the notions of intertextuality, recontextualisation and entextualisation present themselves for further theorizing (Wodak, Fairclough, 2010; Blommaert, 2003).

An important assumption common to various approaches to CDS is that processes of social change are in part processes of change in discourse, and that change in discourse may, subject to certain conditions, have constructive effects on processes of social change more generally. The challenge is to develop theories of social change which coherently integrate discourse and relations between discourses and other elements or moments of the social process, and methodologies for focusing specifically on these relations, and the particular place and impact of discourse, in inter-disciplinary research on social change (Fairclough, 1992; Krzyżanowski, Wodak, 2009). Since events and texts are linked to, affected by and have effects on other events and texts in different places and at different times, the major challenge implies developing ways to address broadly spatial and temporal relationships between events and texts (i.e. intertextuality; Kristeva, 1986).

Struggles for hegemony of various competing narratives of the past which can be reconstructed in a longitudinal way require very subtle context-dependent analyses. In this way, the theorization of contexts becomes crucial to any dialectic analysis (see below: "Levels of context”). Thus, we assume that social and historical change occurs on several levels at different times and with different speed (or sometimes not at all); thus non-simultaneity needs, to be accounted for in differentiated, context-dependent ways. These intricate and complex processes also suggest the necessity of the concept of glocalization: of understanding how more global processes are being implemented, recontextualized and thus changed on local/regional/national levels (Krzyżanowski, Wodak, 2009; "model of circular non-simultaneous transformation").

Recontextualization as one of the salient linguistic processes governing historical change is concretely manifested in the intertextuality and interdiscursivity of texts (Wodak, Fairclough, 2010). The intertextuality of a text is a matter of how elements of other texts (words, phrases, arguments, topics, or larger elements) are incorporated within it; the interdiscursivity of a text is the particular combination of different discourses and different genres that characterizes the text, and how the deployment of particular discourses and genres links the text to other intertextually related texts. Recontextualization is often 
textually realized in the mixing of "new" recontextualized elements and "old" elements, such as particular words, expressions, arguments, topoi, rhetorical devices and so forth, and discourses and genres. The tensions, contradictions and antinomies which recontextualization gives rise to can be textually identified and analysed by focusing upon such textual mixing or hybridity ${ }^{8}$.

\section{Levels of context}

The concept of context is an inherent part of discourse analysis. In the course of investigating complex social problems, it is necessary to draw on multiple theoretical approaches to analyse given contexts and relate these to texts. To make this possible in a meaningful way, decisions must be made about the theoretical foundations and interdisciplinarity of discourse analysis. This is why I have proposed the Four-Level Model of context elsewhere which I summarise briefly below.

This triangulatory approach is based on a concept of context which takes into account four levels:

- the co-text of each utterance or clause;

- the con-text in the macro-text; the genre analysis;

- the socio-political context of the speech event.

The intertextual and interdiscursive relationships of the respective speech event to other relevant events.

When analysing narratives about past events, a systematic investigation of context-dependent layers of debate proves valuable as illustrated, for example, in deconstructing instances of the politics of denial (Heer et al., 2008).

\section{Perspectives}

Although this paper - due to restrictions on space - can only cover part of the most important research on "coping with traumatic pasts" from a discourseanalytic perspective, it is obvious that all dimensions and levels of language and communication can be functionalized to achieve "re/writing of history". This paper aims primarily at raising awareness of the "power of the written and spoken word", in all public and private contexts in our lives. Careful and critical reading/listening and viewing is required in order to understand the implied meanings, which are frequently controversial and conflicting.

8. In a similar vein, Blommaert (2003, p.177) employs the term entextualisation which guides the "production of historical text". Thus Blommaert argues, entextualisation means "setting / desetting / resetting events in particular (morally and politically loaded) time frames, and this in turn involves the usual power differences of entextualisation: access to contextual spaces, the importance of 'the record', orientation towards authoritative voices, shifts in referential and indexical frames and so on". 


\section{References}

Achugar M., 2008, What we Remember: The Construction of Memory in Military Discourse, Amsterdam, Philadelphia, Benjamins.

Anthonissen C., Blommaert J. eds, 2006, Critical Linguistic Perspectives on Coping with Traumatic Pasts: Case Studies, Special Issue, Journal of Language and Politics, Amsterdam, Philadelphia, Benjamins.

Assmann A., 2009, "From collective violence to a common future: four models for dealing with a traumatic past", Memory and Justice, R. Wodak, G. Auer-Boreo eds, Vienna, Passagen Verlag, p. 31-48.

BARNARD C., 2003, "Pearl Harbour in Japanese high school history schoolbooks", Re/ Reading the Past. Critical and Functional Perspectives on Time and Value, J. R. Martin, R. Wodak eds, Amsterdam, Philadelphia, Benjamins, p. 247-271.

BENKE G., WodAK R., 2003, "The discursive construction of individual memories. How Austrian 'Wehrmacht' soldiers remember WWII”, Re/Reading the Past. Critical and Functional Perspectives on Time and Value, J. R. Martin, R. Wodak eds, Amsterdam, Philadelphia, Benjamins, p. 115-138.

Billig M., Condor S., Edwards D., Gane M., Middleton D., Radley A., 1988, Ideological Dilemmas. A Social Psychology of Everyday Thinking, London, Sage.

Blackledge A., 2004, Discourse and Power in a Multilingual World, Amsterdam, Philadelphia, Benjamins.

Blommaert J., 2003, “Orthopraxy, writing and identity”, Re/Reading the Past. Critical and Functional Perspectives on Time and Value, J. R. Martin, R. Wodak eds, Amsterdam, Philadelphia, Benjamins, p.177-194.

- 2005, Discourse, Cambridge, Cambridge University Press

CARrard Ph., 2010, The French Who Fought for Hitler: Memories from the Outcasts, Cambridge, Cambridge University Press.

ChARTERIS-BlACK J., 2006, Politicians and Rhetoric, Basingstoke, Palgrave.

CHILTON P., 2007, "Missing links in mainstram CDA: modules, blends, and the critical instinct", A New Agenda in (Critical) Discourse Analysis, R. Wodak, P. Chilton eds, Amsterdam, Philadelphia, Benjamins, p.19-52.

CZYŻEWsKı M., 2009, "The Polish debate around fear by Jan Tomasz Gross from the perspective of the intermediary discourse analysis", Memory and Justice, R. Wodak, G. Auer-Boreo eds, Vienna, Passagen Verlag, p.147-168.

De Cillia R., Wodak R., 2009a, “Restitution: Yes, but...”, Memory and Justice, R. Wodak, G. Auer-Boreo eds, Vienna, Passagen Verlag, p. 195-212.

- 2009b, Gedenken im «Gedankenjahr». Zur diskursiven Konstruktion österreichischer Identitäten im Jubiläumsjahr 2005, Innsbruck, Studien Verlag.

ENGEL J., WodAK R., 2009, “Kalkulierte Ambivalenz: Storungen und das Gedankenjahr: Die Causen Siegfried Kampl und John Gudenus", Gedenken im "Gedankenjahr». Zur diskursiven Konstruktion österreichischer Identitäten im Jubiläumsjahr 2005, Innsbruck, Studien Verlag, p.79-100.

ENSINK T., 2009, “Resolving antagonistic tensions. Some discourse analytic reflections 
on verbal commemorative practices", Memory and Justice, R. Wodak, G. AuerBoreo eds, Vienna, Passagen Verlag, p.169-194.

Ensink T., SAuer C. eds, 2003, The Art Of Commemoration, Amsterdam, Philadelphia, Benjamins.

FAIRCLough N., 1992, Discourse and Social Change, London, Polity.

ForChtner B., 2010, “Judge-Penitence Discourses in Germany, Denmark, and Austria”, Unpublished PhD Thesis, Lancaster University.

Heer H., Manoschek W., Pollak A., Wodak R. eds, 2008, The Discursive Construction of History: Remembering the Wehrmacht's War of Annihilation, Basingstoke, Palgrave (translated from the German: Wie Geschichte gemacht wird. Zur Konstruktion von Erinnerungen an Wehrmacht und Zweiten Weltkrieg, Vienna, Czernin, 2003).

JUDT T., 2007, Post-War, London, Penguin.

KovÁcs A., WodAK R. eds, 2003, NATO, Neutrality, and National Identity, Vienna, Böhlau. KRISTEVA J., 1986, The Kristeva Reader, T. Moi éd., Oxford, Basil Blackwell.

KRZYŻANOWSKI M., WODAK R., 2009, "Theorising and analysing social change in Central and Eastern Europe: the contribution of critical discourse analysis", Discourse and Transformation in Central and Eastern Europe, A. Galasińska, M. Krzyżanowski eds, Basingstoke, Palgrave, p. 17-40.

LoITfELLner S., 2008, “The appalling toll in Austrian lives...”, The Discursive Construction of History: Remembering the Wehrmacht's War of Annihilation, H. Heer et al. eds, Basingstoke, Palgrave, p. 155-174.

MARTIN J. R., WODAK R. eds, 2003, Re/reading the past. Critical and Functional Perspectives on Time and Value, Amsterdam, Philadelphia, Benjamins.

Musolff A., 2009, "Metaphor in the history of ideas and discourses: how can we interpret a medieval version of the body-state analogy?", Metaphor and Discourse, Musolff A., Zinken J. eds, Basingstoke, Palgrave, p. 233-247.

PelinkA A., 2009, "Justice, truth, and peace. Three dimension of consequences", Memory and Justice, R. Wodak, G. Auer-Boreo eds, Vienna, Passagen Verlag, p. 48-66.

PollaK A., 2002, Die Wehrmachtslegende in Österreich, Vienna, Böhlau Verlag.

Pollak A., Wodak R., 2008, “Crime scene: Wehrmacht exhibition”, The Discursive Construction of History: Remembering the Wehrmacht's War of Annihilation, H. Heer et al. eds, Basingstoke, Palgrave, p. 207-226.

ReISIgL M., 2008, "Rhetoric of political speeches", Analyzing the Public Sphere: Handbook of Applied Linguistics, vol. IV, R. Wodak, V. Koller eds, Berlin, De Gruyter.

Ribeiro F., 2010, “The Discursive Construction of Portuguese Identity”, Unpublished PhD Thesis, Lancaster University.

RICHARDSON J. E., WODAK R., 2009a, “The impact of visual racism: Visual arguments in political leaflets of Austrian and British far-right parties", Controversia, 6, p. 45-77.

- 2009b, "Recontextualising fascist ideologies of the past: right-wing discourses on employment and nativism in Austria and the United Kingdom", Critical Discourse Studies, 6 (4), p. 251-267.

Richardson J. E., Wodak R. eds, 2009c, Critical Discourse Studies, 6 (10), Discourse, History, and Memory, Special Issue.

SLAVICKOVA T., 2010, “The Memorial Day Speeches of US Presidents”, Unpublished PhD 
Thesis, Lancaster University.

Stockholm-BANKe C., 2009, "The Legacies of the Holocaust in Scandinavian small state foreign policy", Justice and Memory. Confronting traumatic pasts. An international comparison, R. Wodak, G. Auer-Boreo eds, Vienna, Passagen Verlag, p. 265-277.

Suleiman U., 2010, Too Many Truths... Too Many Broken Dreams. At-Taqiyya in ArabPalestinian Political Discourse, Amsterdam, Philadelphia, Benjamins.

ThIeSMeYer L. ed., 2003, Discourse and Silencing, Amsterdam, Philadelphia, Benjamins. UHL H., 2008, “Interpreting the 'War of Annihilation'”, The Discursive Construction of History: Remembering the Wehrmacht's War of Annihilation, H. Heer et al. eds, Basingstoke, Palgrave, p. 251-266.

VAN DIJK T. A., 1993, “Denying racism: elite discourse and racism”, Racism and Migration in Western Europe, J. Solomos, J. Wrench eds, Oxford, Berg, p. 179-193.

Verdoolaege A., 2008, Reconciliation Discourse, Amsterdam, Philadelphia, Benjamins.

WodAK R., 2001, "The discourse-historical approach", Methods of Critical Discourse Analysis, R. Wodak, M. Meyer eds, London, Sage, p.63-94.

- 2006a, "History in the making: the making of history", Journal of Language and Politics, 5 (1).

- 2006b, "Blaming and denying", Elsevier Encyclopedia for Language and Linguistics ( $2^{\text {nd }}$ edition), K. Brown ed., Oxford, Elsevier.

- 2007, "Pragmatics and critical discourse analysis. A cross-disciplinary analysis, Pragmatics and Cognition, 15 (1), p. 203-225 (translated into French : "Pragmatique et analyse de discours critique: un exemple d'une analyse à la croisée des disciplines", Semen, 27, 2009, p. 97-126).

- 2009, The Discourse of Politics in Action: Politics as Usual, Basingstoke, Palgrave.

WodAK R., De Cillia R., 2006, “Politics and Language: Overview”, Encyclopedia of Language and Linguistics ( $2^{\text {nd }}$ revised edition), K. Brown ed., vol. 9, Oxford, Elsevier, p.707-719. [ne faudrait-il pas que De Cillia apparaisse avant Wodak? Même question pour tous les titres de Wodak et autres cités ci-après]

- 2007, "Commemorating the past: the discursive construction of official narratives about the rebirth of the Second Austrian Republic", Discourse and Communication, 1 (3), p. 337-363.

WodAk R., FAirclough N., 2010, “Recontextualizing European higher education policies: the cases of Austria and Romania”, Critical Discourse Studies, 7 (1), p. 19-40.

WodAk R., De Cillia R., ReISIgl M., LIEBHART K., 2009 [1999], The Discursive Construction of National Identity, Edinburgh, Endingburgh University Press ( $2^{\text {nd }}$ revised edition).

Wodak R., Menz F., Mitten R., Stern F., 1994, Die Sprachen der Vergangenheiten. Öffentliches Gedenken in österreichischen und deutschen Medien, Frankfurt-amMain, Suhrkamp.

Wodak R., Pelikan J., Nowak P., Gruber H., De Cillia R., Mitten R., 1990, «Wir sind alle unschuldige Täter». Diskurshistorische Studien zum Nachkriegsantisemitismus, Frankfurt-am-Main, Suhrkamp.

Wodak R., Auer-Boreo G. eds, 2009, Memory and Justice, Vienna, Passagenverlag.

ZIMmERMAN M., 2009, “Israel's prenatal memory: born 1948 - traumatized 1938”, Memory and Justice, R. Wodak, G. Auer-Boreo eds, Vienna, Passagen Verlag, p. 309-316. 


\section{Les politiques linguistiques}

Dans le monde contemporain, la diversité de traitement des contacts de deux ou plusieurs langues au sein du même espace sociétal, parlées par des communautés linguistiques (Labov, 1976) différentes, est étonnante (voir par ex. Boyer et Dumont, 1987). Et s’il est un domaine où la sociolinguistique, sous l'appellation de sociolinguistique appliquée, a acquis par le caractère thérapeutique de ses interventions une importante légitimité sociale, c'est bien celui des politiques linguistiques.

Il est le plus souvent question de politiques linguistiques institutionnelles, mais il ne faut pas oublier que les interventions sur les questions de langue(s) ne sont pas l'apanage des États : des structures associatives locales, des organisations non gouvernementales, des collectivités territoriales comme certaines régions en France (au travers de politiques publiques spécifiques en faveur de langues «minoritaires» et/ou «régionales») peuvent fort bien, précisément dans les cas de problèmes linguistiques sociétaux plus ou moins importants, tenter de peser par une action de nature militante ou/et réglementaire sur la situation sociolinguistique concernée.

\section{Politique, planification, aménagement... linguistique : l'émergence de la sociolinguistique appliquée}

La notion de politique linguistique, appliquée en général à l'action d'un État', désigne les choix, les objectifs, les orientations qui sont ceux de cet État en matière de langue(s), choix, objectifs et orientations suscités en général (mais pas obligatoirement) par une situation intra- ou intercommunautaire préoccupante en matière linguistique (on songe à l'Espagne au sortir du franquisme ou à la Yougoslavie de Tito) ou parfois même ouvertement conflictuelle (comme c'est le cas de la Belgique aujourd'hui). L'expression politique linguistique employée ici comme entrée dans ce sous-champ de la sociolinguistique qu'est la sociolinguistique appliquée (à la gestion des langues) semble avoir été

Université Montpellier 3, DIPRALANG

henri.boyer@univ-montp3.fr

1. Le ${ }^{\circ} 52$ (septembre 1997) de Mots. Les langages du politique était intitulé, sur la première de couverture : Politiques linguistiques et, dans le sommaire, L'État linguiste. 
utilisée tardivement (dans les années soixante-dix du $20^{\mathrm{e}}$ siècle) à la fois aux États-Unis et en Europe (Calvet, 1996, p.6), bien après celle de planification linguistique, traduction de language planning dont la paternité revient, selon Louis-Jean Calvet (1996, p.4), à Einar Haugen (1959), expression qui se verra par la suite concurrencée par normalisation linguistique (Aracil, 1965, pour le domaine catalan-espagnol) et aménagement linguistique (Corbeil, 1980, pour le domaine québécois-francophone). Enfin Jean-Baptiste Marcellesi et Louis Guespin proposent le terme glottopolitique avec, semble-t-il, le souhait d'élargir la qualification afin d' "englober tous les faits de langage où l'action de la société revêt la forme du politique»(Guespin, Marcellesi, 1986, p.5)².

\section{Aspects techniques et juridiques}

Les notions recensées correspondent pour l'essentiel à deux niveaux d'intervention (et donc d'analyse) en matière de gestion des langues. Car pour qu'une politique linguistique (comme toute politique publique : éducative, sanitaire, environnementale...) ne s'arrête pas au stade des déclarations et passe à l'action, il faut qu'elle mette en place un dispositif et des dispositions : on passe à un autre niveau, celui de l'intervention concrète, et c'est alors qu'on peut parler de planification, ou d'aménagement ou de normalisation linguistiques.

À cet égard, une politique linguistique peut :

- concerner telle langue dans ses formes : il peut s'agir alors d'une intervention de type normatif (visant, par exemple, à déterminer une forme standard, à codifier des fonctionnements grammaticaux, lexicaux, phonétiques..., ou encore à modifier une orthographe, etc., et à diffuser officiellement les [nouvelles] normes ainsi fixées auprès des usagers) ;

- concerner les fonctionnements socioculturels de telle langue, son statut, son territoire, face aux fonctionnements socioculturels, au(x) statut(s), $\mathrm{au}(\mathrm{x})$ territoire(s) d'une autre/d'autres langue(s) également en usage dans la même communauté, avec des cas de figures variables (complémentarité, concurrence, domination, etc.).

Une politique linguistique peut aussi présenter une double visée : linguistique et socioculturelle, et les deux types d'intervention évoqués sont alors parfaitement solidaires. C'est ce qu'on entend par normalisation en Espagne dans la période actuelle où, en Catalogne par exemple, la normalisation sociolinguistique officielle du catalan implique la prise en compte de la normativisation linguistique (grammaticale, lexicale, orthographique...), déjà largement réalisée

2. Dernièrement, Louis-Jean Calvet a introduit un degré supplémentaire dans le paradigme : celui de la «politologie linguistique». Considérant les politiques linguistiques comme des «pratiques», Calvet souhaite œuvrer pour « une science [politique] de ces pratiques, la politologie linguistique» (2002, p. 10). Néanmoins l'ensemble des analyses contenues dans l'ouvrage qui affiche ce projet continuent de se focaliser essentiellement sur la mondialisation et les politiques linguistiques. 
dans le premier tiers du $20^{\mathrm{e}}$ siècle ainsi que l'enrichissement terminologique permanent (Boyer, 1996, p.103-104) et par ailleurs la promotion de normes d'usage du catalan dans tous les domaines de la vie sociale. La normalisation est pour les sociolinguistes catalans la seule réponse pertinente à la dynamique de substitution que ne manque pas de créer un conflit diglossique en faveur de la langue dominante, conformément aux hypothèses de L. V. Aracil :

[...] une véritable normalisation ne peut jamais se limiter aux aspects «purement» linguistiques, mais elle doit prendre en compte en même temps un tas de facteurs clairement "sociaux» et même essentiellement politiques. Ce qu'il faut en tout cas c'est assurer un équilibre dans le cercle fonctionnel car il serait assez curieux de penser qu'un idiome "vivant» puisse accomplir la plénitude de ses fonctions sociales et culturelles en étant dépourvu de l'intégrité des fonctions linguistiques indispensables ou en en étant privé de façon coercitive. L'action est condamnée à l'échec si elle n'avance pas simultanément sur un double front : linguistico-culturel (développement des fonctions socioculturelles de la langue) et sociopolitique (réorganisation des fonctions linguistiques de la société). [Ainsi] la normalisation est une véritable macrodécision qui, comme par exemple les macrodécisions économiques, tend à orienter l'avenir d'une communauté et suppose l'exercice d'un certain pouvoir. On comprend pourquoi la normalisation efficace exige, ou bien la pleine indépendance politique (= souveraineté), ou du moins un degré substantiel de self-government de la communauté linguistique concernée. (Aracil,1982, p.33; c'est moi qui souligne; je traduis du catalan)

Du reste, le couple notionnel normalisation/normativisation correspond assez bien à la dichotomie proposée par Heinz Kloss (1969) et adaptée par Einar Haugen (1983) dans le cadre d'une modélisation plus complexe, en vigueur dans la littérature anglo-saxonne du domaine : status planning (planification du statut) / corpus planning (planification du corpus); le status planning «vise le statut social de la langue»; quant au corpus planning, il s'agit de «l'aménagement de la langue elle-même» (Daoust, Maurais, 1987, p. 9-10).

Si l'on veut mettre en synergie l'essentiel des modélisations et notions disponibles et dont il a été fait état dans ce qui précède, on obtient la figuration suivante :

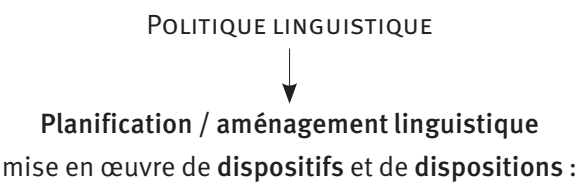

interventions sur une langue

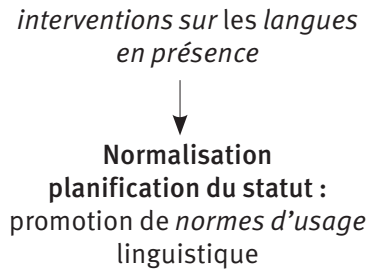

Mots. Les langages du politique $n^{\circ} 94$ novembre $2010 \bullet 69$ 
Pour ce qui concerne l'appareil juridico-administratif au service des politiques linguistiques étatiques (dont le coût en termes financiers peut être très important), il y a donc diversité, qu'il soit mis en place au niveau central ou au niveau des collectivités territoriales (comme la Communauté autonome en Espagne, le district en Finlande, le canton ou la commune en Suisse...) ou à plusieurs niveaux à la fois. Ainsi en France, la politique linguistique en faveur des langues de France autres que le français, au nombre de 75 (qui prend en compte les langues régionales et minoritaires territorialisées, mais aussi les langues anciennement [et durablement?] installées sur le sol français, mais non territorialisées - l'arabe dialectal, le berbère, le romani...) (Cerquiglini, 1999) incombe institutionnellement à la Délégation générale à la langue française et aux langues de France (institution qui, à l'origine, s'occupait essentiellement de la mise œuvre de la politique linguistique du gouvernement en faveur de la défense du français). Cependant, on l'a dit, des régions où une ou deux langues territorialisées autres que le français (l'occitan, le breton, le catalan, le basque...) sont en usage, peuvent faire l'objet de politiques linguistiques de protection, appuyées sur des enquêtes sociolinguistiques3, mettant en œuvre des campagnes de sensibilisation et de promotion, d'enseignement, de production de matériels divers, en particulier pédagogiques, etc. On observe souvent une instrumentalisation de l'identité linguistique (et donc culturelle) régionale. Cependant, ces politiques publiques contribuent à légitimer la survie de ces langues (en général stigmatisées en même temps que célébrées), à accroître leurvisibilité dans l'espace public (au travers de signalisations bilingues ou de manifestations festives, par exemple) 4 .

Le dispositif au niveau étatique peut se limiter à une Académie de la langue et, en guise de dispositions, on peut ne trouver qu'un article dans la Constitution. Mais on peut aussi observer la création d'autres instances de gestion, comme un ministère, un office, une direction, des commissions, des conseils

3. Cf. les enquêtes sur la pratique et les représentations de l’occitan réalisées par Média Pluriel Méditerranée pour la Région Languedoc-Roussillon (1991 et 1997) et pour la Région Aquitaine (1997). Plus récemment, la Région Aquitaine, en partenariat avec les cinq conseils généraux concernés, a fait réaliser par une entreprise spécialisée, Téléperformance Midi-Aquitaine, en octobre et novembre 2008, une enquête sociolinguistique par questionnaire téléphonique auprès d'un échantillon représentatif de 6002 Aquitains (enquête dont les résultats ont été diffusés en décembre 2008 sur le site du conseil régional ) : "Présence, pratiques et perceptions de la langue occitane».

4. Étienne Hammel, qui fut chargé de mission pour les langues régionales (catalan, occitan) en Languedoc- Roussillon, distingue trois modèles d'interventions : «Le plus ancien fait principalement appel au mouvement associatif pour orienter et dynamiser l'action. Il prend fréquemment la forme d'un Conseil [...] de personnalités qualifiées [...]. Un second modèle, développé après 1985 , repose sur la prise en charge directe par l'institution, au moyen d'une ligne budgétaire et de personnel administratif. [...] Une forte volonté politique, enfin, manifestée récemment par certains élus qui prennent directement les affaires en main, se traduit par des développements rapides et une diffusion de la préoccupation pour les langues et cultures régionales dans tous les secteurs de l'action de la collectivité, en fonction de ses compétences (tourisme, formation, signalisation, documents écrits, etc.). » Hammel, 1996, p. 15-16. 
et la prolifération de textes réglementaires : décrets, arrêtés, circulaires et parfois le vote de lois linguistiques.

Par ailleurs, la réalisation d'une politique linguistique se doit d'être attentive au respect de deux principes fondamentaux du droit en matière de plurilinguisme :

- le principe de personnalité, selon lequel «le choix de la langue [relève] des droits personnels de l'individu » (Mackey, 1976, p. 82);

- le principe de territorialité, qui suppose une territorialisation de la gestion du plurilinguisme, laquelle peut revêtir des dimensions très variables, comme on l'a dit (région, canton, commune...). C'est ce principe qui inspire majoritairement les aménagements/planifications linguistiques.

\section{Idéologie(s) et choix de politique linguistique}

Généralement, on évalue à plus de 6000 le nombre des langues en usage dans le monde : il est donc clair que le monolinguisme y est l'exception et que le plurilinguisme est la situation la plus répandue sur l'ensemble des États. Il en va de même en Europe, certes avec une pluralité moindre, mais cependant souvent menacée : d'où la mise en œuvre par le Conseil de l'Europe d'une disposition supra-étatique de politique linguistique : la Charte européenne des langues régionales ou minoritaires (Woehrling, 2005), car l'espace géopolitique européen est souvent celui où s'est le plus développé l'idéal de l'ÉtatNation, c'est-à-dire un idéal d'État monolingue qui tend à associer un même territoire, une seule organisation politico-administrative et une langue unique. L'État français est la concrétisation de cet idéal d'État-Nation qui obsède bon nombre de revendications identitaires (et nationalistes) sur le continent européen (cf. l'« espace ex-yougoslave») (Baggioni, 1997; Boyer éd., 2004).

En matière de plurilinguisme et en relation avec la «mondialisation », on peut considérer que les options de politique linguistique ne sont pas légion: à un pôle libéral, qui fait prévaloir le laisser-faire, s'oppose un pôle interventionniste à deux variantes, parfois associées : celle des droits universels en matière linguistique et de l'écologie linguistique, qui défend le principe de sauvegarde de la diversité linguistique et donc de défense systématique du plurilinguisme, et le positionnement identitaire en faveur de la langue communautaire, dont le nationalisme linguistique est le cas de figure le plus achevé (Boyer, 2008).

Le «pôle libéral» n'est pas difficile à caractériser : il accepte la logique du marché des langues dominant (localement, internationalement). On peut en trouver des versions caricaturales (s'appuyant sur des discours d'inspiration étroitement économiste) aux meilleures sources. Ainsi chez De Swaan (2001), à propos de la « compétition entre communautés linguistiques», il est question 
d'«investissement», de «bénéfices [...] attendus», de «coût»... puisque les langues sont des «biens hypercollectifs »... (voir Boyer, 2007).

Quant au pôle interventionniste, il est aujourd'hui prioritairement représenté par l'écologie linguistique. Ce qui est intéressant dans cette vision «altermondialiste ", c'est le double mouvement des interventions qui est prôné, qui articule des «stratégies de haut en bas » visant à «mettre en place des politiques linguistiques à un niveau local, régional et international qui fassent partie d'une planification politique et de gestion générale des ressources» (ibid., p. 213), mais aussi des «stratégies de bas en haut» car «accorder trop d'attention aux politiques officielles peut s'avérer contre-productif en l'absence d'autres activités aux niveaux inférieurs» (ibid., p. 191). Ainsi, «la préservation d'une langue doit d'abord commencer dans la communauté elle-même, grâce à des efforts volontaires, et être financée de bas en haut par les ressources de la communauté» (ibid., p. 202).

Le même pôle interventionniste présente une deuxième variante, la revendication identitaire, qui peut se présenter sous la modalité du nationalisme linguistique : une option qui semble avoir eu le vent en poupe durant la dernière période 5 . Cette option est, quoi qu'on en dise, la base idéologique de certains retournements de substitution linguistique (Reversing Language Shift, dans les termes du sociolinguiste Fishman) dans lesquels la loyauté linguistique des usagers n'a pas failli, dont trois cas proprement spectaculaires (Fishman, 1991, présenté par Vallverdú, 1993) : l'hébreu moderne en Israël, le français au Québec et le catalan en Espagne dans la Communauté autonome de Catalogne.

Pour prendre l'exemple catalan, durant le $20^{\circ}$ siècle, les catalanistes ont su enrichir la construction idéologique du nationalisme linguistique (commencée dans les dernières décennies du 19e), et tout particulièrement dans la lutte contre la dictature franquiste. Le pouvoir nationaliste qui a présidé aux destinées du gouvernement autonome de la Catalogne (la Generalitat de Catalunya) durant deux décennies a su se faire le chantre et le défenseur intraitable de la langue catalane, en contribuant à instaurer en Catalogne autonome un dispositif de politique linguistique exemplaire (Boyer, Lagarde éd., 2002), et en sachant tenir un discours public à vocation consensuelle mais inspiré par un ferme positionnement nationaliste non-indépendantiste. Il est clair cependant que la «langue nationale» des Catalans n'a pas totalement neutralisé à son avantage la dynamique de substitution héritée du franquisme en faveur du castillan : des faiblesses dans la normalisation officielle sont patentes, malgré d'incontestables succès dans presque tous les secteurs de la communication

5. Et même si d'aucuns considèrent un peu hâtivement que « les revendications actuelles prennent peut-être moins souvent la forme de nationalisme étatique et plus souvent la forme de revendications de droits linguistiques humains; l'écologie remplace le nationalisme comme idéologie légitimante de base» (Heller, 2002, p. 179). 
sociale et de la vie de la communauté, qui autorise certains observateurs à considérer qu'il y a bien globalement un retournement de situation sociolinguistique.

Et c'est bien dans le domaine de l'évaluation des politiques linguistiques que des avancées devraient être faites. Certes, il existe au sein des dispositifs les plus sophistiqués des structures spécifiques mises en place pour observer et évaluer rigoureusement les résultats obtenus : on songe par exemple à l'Institut de Sociolingüística Catalana et aux études qu'il a produites tout au long de la mise en œuvre de la normalisation linguistique institutionnelle, mais justement, le plus souvent, on peut reprocher à ce type d'évaluation d'être de l'autoévaluation (ce qui du reste n'est déjà pas si mal...).

Par ailleurs, une évaluation des politiques linguistiques digne de ce nom ne saurait se satisfaire des notions trop générales de « réussite » et d' "échec » (voir Truchot et Huck, 2008), comme le montre en particulier l'exemple catalan : la complexité des processus en cause requiert à la fois des évaluations macrosociolinguistiques (d'ordre quantitatif) et des observations microsociolinguistiques (d'ordre qualitatif), secteur (communicationnel) par secteur, et aussi bien sur le plan des représentations et attitudes que sur le plan des pratiques et comportements effectifs.

\section{Références}

ARACIL L. V., 1982 [1965], «Conflicte lingüístic i normalització linguistic a l’Europa nova », Papers de socio-lingüística, Barcelone, La Magrana.

BAGGIONI D., 1997, Langues et nations en Europe, Paris, Payot et Rivages.

BouRdieu P., 1982, Ce que parlerveut dire, Paris, Fayard.

- 1983, "Vous avez dit "populaire”?", Actes de la recherche en sciences sociales, $\mathrm{n}^{\circ} 46$, p. 98-105.

BOYER H., 1996, Éléments de sociolinguistique, Paris, Dunod.

- 2007, "Les langues minoritaires à l'encan? De la "course à la 'part du marché”" à l'“acharnement thérapeutique”. Discours sur la dimension linguistique de la mondialisation», Territoires et promotion des langues, A. Viaut éd., Bordeaux, MSH d'Aquitaine, p. 33-45.

- 2008, Langue et identité. Sur le nationalisme linguistique, Limoges, Lambert-Lucas.

BOYER H. éd., 2004, Mots. Les langages du politique, nº74, mars, Langue(s) et nationalisme(s).

Boyer H., Dumont P. éd., 1987, Études de linguistique appliquée, n65, janvier-mars, Politiques linguistiques (Études de cas).

Boyer H., LAGARDE Ch. éd., 2002, L'Espagne et ses langues. Un modèle écolinguistique?, Paris, L'Harmattan.

CALVET L.-J., 1987, La guerre des langues et les politiques linguistiques, Paris, Payot.

- 1996, Les politiques linguistiques, Paris, PUF.

- 2002, Le marché aux langues, Paris, Plon. 
CERQUIG LINI B., 1999, Les langues de France. Rapport au ministre de l'Éducation nationale, de la recherche et de la technologie et à la ministre de la Culture et de la Communication, Paris, La Documentation française.

CorbeIL J.-C., 1980, L’aménagement linguistique du Québec, Montréal, Guérin.

Daoust D., Maurais J., 1987, «L'aménagement linguistique», Politique et aménagement linguistiques, J. Maurais éd., Québec, Gouvernement du Québec, Conseil de la langue française, p. 7-46.

FISHMAN J. A., 1991, Reversing Language Shift. Theorical and Empirical Foundations of Assistance to Threatened Languages, Cleveland-Philadelphia-Adelaïde, Multilingual Matters.

GUeSPIN L., MARCELLESI J.-B., 1986, «Pour la glottopolitique », Langages, n 83, p. 5-31.

HAMmel E., 1996, Aide-mémoire. Langues et cultures régionales et Région LanguedocRoussillon, 1985-1996, Perpignan, Trabucaire.

Haugen E., 1959, "Planning in modern Norway», Anthropological Linguistics, vol.1, no 3, p. 8-21.

- 1983, "The implementation of corpus planning : theory and practice», Progress in Language Planning, J. Cobarrubias, J. A. Fishman éd., La Haye, Mouton, p. 269-289.

HeLLer M., 2002, "L'écologie et la sociologie du langage», L'écologie des langues / Ecology of Languages, A. Boudreau, L. Dubois, J. Maurais, G. McConnell éd., Paris, L'Harmattan, p. 175-193.

KLoss H., 1969, Research Possibilities on Group Bilingualism : A Report, Québec, CIRB. LABOv W., 1976, Sociolinguistique, Paris, Minuit.

MACKEY W. F., 1976, Bilinguisme et contact des langues, Paris, Klincksieck.

MAURAIS J. éd., 1987, Politique et aménagement linguistiques, Québec, Gouvernement du Québec, Conseil de la langue française.

NinYoles R. L., 1975, Estructura social y política lingüística, València, Fernando Torres.

Nettle D., Romaine S., 2003, Ces langues, ces voix qui s'effacent, Paris, Autrement.

TRUCHOT C., HuCK D. éd., 2008, Les Cahiers du GEPE, nº 1, L'analyse des pratiques d'évaluation des politiques linguistiques. Une entrée pourl'étude des politiques linguistiques?

VAlLVERdú F., 1993, "Sobre el capgirament de la substitució lingüística. Un suggestiu estudi de Joshua A. Fishman », Treballs de sociolingüística catalana, nº 11, p.17-18.

WoEHRLING J.-M., 2005, La Charte européenne des langues régionales ou minoritaires. Un commentaire analytique, Strasbourg, Conseil de l'Europe. 